\title{
Hubungan Eosinopenia dan Rasio Neutrofil/Limfosit dengan Procalcitonin pada Pasien Sepsis
}

\author{
Ajeng Kurnia Wardhani ${ }^{1}$, Muji Rahayu², Djunaedi Wibawa ${ }^{3}$, Ariosta Setyadi ${ }^{2}$
}

\begin{abstract}
Abstrak
Procalcitonin adalah biomarker yang bermanfaat mendiagnosis sepsis, tetapi mahal dan waktu pemeriksaan lama. Eosinopenia dan rasio neutrofil/limfosit merupakan alternatif yang lebih murah dan cepat, namun efektivitasnya belum diketahui dengan jelas. Tujuan: Menentukan hubungan eosinopenia dan rasio neutrofil/limfosit terhadap procalcitonin pada pasien sepsis. Metode: Penelitian ini adalah analitik observasional dengan pendekatan belah lintang. Subjek penelitian 43 pasien sepsis yang dirawat di RSUP Dr.Kariadi bulan Desember 2018 sampai Juni 2019 , ada 22 pasien wanita dan 21 pria dengan kisaran usia 25-84 tahun. Data kadar procalcitonin, jumah eosinofil, neutrophil dan limfosit diambil secara retrospektif dari catatan medis pasien. Pasien dianggap sepsis bila menunjukkan nilai skor SOFA $\geq 2$. Hasil: Didapatkan kadar procalcitonin antara 2,19 - 87,29 $\mathrm{ng} / \mathrm{mL}$ dengan median 13,8 ng/mL, kadar eosinofil antara $0-0,01 \times 10^{3} / \mu \mathrm{L}$ dengan median $0,01 \times 10^{3} / \mu \mathrm{L}$, serta rasio neutrofil/limfosit antara 7,59-68,36 dengan median 19,39. Uji korelasi spearman tidak menemukan hubungan yang bermakna antara kadar procalcitonin dengan kondisi eosinopenia $(p=0,929 ; r=0,014)$ dan rasio neutrofil/limfosit $(p=0,879 ; r=-0,024)$. Peningkatan kadar procalcitonin $\geq 2 \mathrm{ng} / \mathrm{mL}$, kondisi eosinopenia dengan kadar eosinofil absolut $\leq 0,05 \times 10^{3} / \mu \mathrm{L}$, serta peningkatan rasio neutrofil/limfosit $\geq 5$ diperkirakan sebagai biomarker yang bermanfaat untuk menegakkan diagnosis sepsis, namun tidak menemukan adanya hubungan yang bermakna antara berbagai biomarker tersebut. Simpulan: Hasil penelitian ini belum mendukung penggunaan jumlah eosinofil dan rasio neutrofil/limfosit sebagai pengganti procalcitonin untuk membantu menegakkan diagnosis sepsis.
\end{abstract}

Kata kunci: eosinopenia, procalcitonin, rasio neutrofil/limfosit, sepsis

\begin{abstract}
Procalcitonin is a useful biomarker to help diagnose sepsis, but the cost is expensive, and it requires a relatively long waiting time. Eosinopenia and neutrophil/lymphocyte ratio is cheaper and faster alternatives, but the efficacy is unclear. Objectives: To determined the correlation between eosinopenia and neutrophil/lymphocyte ratio on procalcitonin in patients with sepsis. Methods. It was a cross-sectional analytical observational study. The subjects were 44 patients with sepsis (22 females and 21 males) aged 25-84 years that were admitted to RSUP Dr. Kariadi from December 2018-June 2019. Procalcitonin levels, eosinophil, neutrophil, and lymphocyte count data were retrospectively collected from medical records. Patients were classified as having sepsis with a SOFA score of $\geq 2$. Results. Patients with sepsis in the current study showed procalcitonin levels between 2,19-87,29 $\mathrm{ng} / \mathrm{mL}$ with a median 13,8 $\mathrm{ng} / \mathrm{mL}$, eosinophil count between $0-0.01 \times 10^{3} / \mu \mathrm{L}$ with a median $0,01 \times 10^{3} / \mu \mathrm{L}$, and neutrophil/lymphocyte ratio between 7,59 - 68,36 with median 19,39. Spearman's correlation test found no significant correlation between procalcitonin levels and eosinopenia $(p=0.929 ; r=0.0,014)$ or neutrophil/lymphocyte ratio ( $p=$ $0.879 ; r=-0.024)$. $A \geq 2 \mathrm{ng} / \mathrm{mL}$ increase in procalcitonin levels, eosinopenia with an absolute eosinophil count of $\leq 0.05$ $\times 10^{3} / \mu \mathrm{L}$, There was no evidence of a significant correlation between these biomarkers. Conclusion: This study has not been able to support the use of eosinophil count and neutrophil/lymphocyte ratio as alternatives for procalcitonin as a biomarker in the diagnosis of sepsis.
\end{abstract}

Keywords: eosinopenia, procalcitonin, neutrophil/lymphocyte ratio, sepsis 
Affiliasi penulis : 1 Program Pendidikan Dokter Spesialis Patologi Klinik, Fakultas Kedokteran, Universitas Diponegoro, Semarang.

2 Bagian Patologi Klinik, Fakultas Kedokteran, Universitas Diponegoro Semarang, ${ }^{3}$ RSUD Pemalang,

Korespondensi: Ajeng Kurnia Wardhani, Email:

ajeng3005@gmail.com, Telp: 082138898826

\section{PENDAHULUAN}

Sepsis merupakan suatu kondisi disfungsi organ yang mengancam jiwa dan disebabkan oleh terjadinya respon abnormal dari pejamu terhadap kondisi infeksi berat. ${ }^{1}$ Angka kejadian sepsis nampak terus mengalami peningkatan, terutama pada populasi usia lanjut yang memiliki lebih banyak faktor komorbiditas. ${ }^{2,3}$ Sepsis berhubungan dengan angka mortalitas yang tinggi dan diperkirakan sebagai salah satu penyebab morbiditas serta mortalitas yang utama pada pasien dengan penyakit kritis secara global. ${ }^{4-6}$ Data epidemiologi global dari penelitian Intensive Care Over Nations (ICON) melaporkan angka kejadian sepsis pada pasien ICU sebesar 29,5\%. Pasien sepsis juga dilaporkan memiliki angka mortalitas lebih tinggi dibandingkan pasien ICU yang dirawat atas indikasi lain (25,8\% dibandingkan 16,2\%), sedangkan angka mortalitas pasien sepsis yang dirawat di luar unit rawat intensif adalah sebesar $35,3 \%{ }^{4}$

Angka harapan hidup pasien sepsis setelah 72 jam dilaporkan akan mengalami penurunan sekitar $7,7 \%$ per jam bila terjadi keterlambatan pemberian terapi antimikroba yang tepat dan adekuat pada awal terjadinya infeksi, sehingga menunjukkan pentingnya peranan diagnosis sepsis secara dini. ${ }^{7}$ Pasien sepsis yang berhasil bertahan hidup juga sering mengalami sekuele jangka panjang seperti disabilitas fisik, psikologis maupun kognitif yang dapat mengurangi kualitas hidup serta meningkatkan beban biaya perawatan kesehatan semasa hidupnya. ${ }^{1,8}$ Diagnosis segera dilanjutkan dengan pemberian terapi dini dilaporkan dapat memperbaiki luaran dan prognosis pasien sepsis. ${ }^{5,9}$

Salah satu masalah utama yang ditemui dalam menegakkan diagnosis sepsis adalah belum tersedianya jenis pemeriksaan diagnostik yang dapat dengan mudah mengidentifikasi pasien sepsis secara akurat. ${ }^{10}$ Pemeriksaan standar baku emas berupa kultur mikrobiologi umumnya memerlukan waktu yang relatif lama, yaitu antara 48-72 jam, sehingga tidak dapat diandalkan untuk menjadi dasar pemberian terapi klinis secara dini. ${ }^{11,12}$ Hasil kultur darah yang positif umumnya hanya diperoleh pada sekitar $20-30 \%$ kasus yang menunjukkan adanya manifestasi klinis sepsis. ${ }^{12}$ Beberapa tanda dan gejala klinis yang sering ditemui pada kasus infeksi dan hasil pemeriksaan laboratorium rutin untuk sepsis seperti CRP atau hitung leukosit juga nampak memiliki tingkat akurasi diagnostik yang relatif rendah. Saat berada dalam kondisi infeksi berat, kadar sejumlah sitokin proinflamasi seperti TNF- $\alpha$, IL-1 $1 \beta$, atau IL- 6 sering hanya mengalami peningkatan untuk sementara waktu atau secara intermiten, bahkan kadang tidak mengalami peningkatan yang bermakna. ${ }^{13}$ Dengan alasan tersebut, mulai digunakan berbagai jenis penanda klinis atau biomarker yang diharapkan dapat memberikan informasi tambahan untuk membantu dokter menegakkan diagnosis secara cepat dan akurat, sehingga dapat dilakukan pemberian terapi secara cepat dan tepat. ${ }^{11,14}$ Suatu biomarker sepsis bermanfaat secara klinis, apabila dapat memberikan informasi yang dibutuhkan untuk membedakan antara sepsis yang disebabkan oleh infeksi bakteri dengan kondisi Sindrom Respon Inflamasi Sistemik (SIRS) yang disebabkan oleh penyebab non-infeksius secara akurat, cepat, dan hemat. ${ }^{14}$ Biomarker yang saat ini dianggap bermanfaat dalam membantu menegakkan diagnosis sepsis adalah procalcitonin.

Procalcitonin (PCT) merupakan suatu prekursor dari hormon calcitonin yang disintesis secara fisiologis oleh sel tiroid C dan sudah banyak diteliti penggunaannya sebagai biomarker pada berbagai penyakit infeksi, termasuk sepsis. Kadar PCT serum umumnya sangat rendah $(<0,1 \mu \mathrm{g} / \mathrm{mL})$ pada kondisi fisiologis normal, akan tetapi pada kondisi infeksi bakteri akan terjadi sintesis PCT di berbagai jaringan neuroendokrin ekstra-tiroid. Sekresi PCT sistemik merupakan salah satu komponen dari respon inflamasi yang muncul akibat terjadinya infeksi bakteri sistemik. ${ }^{14}$ Beberapa penelitian menemukan bahwa procalcitonin merupakan salah satu biomarker sepsis yang dianggap paling menjanjikan. ${ }^{15-21}$ Penggunaan jenis biomarker ini sayangnya memiliki beberapa kekurangan, antara lain seperti harganya yang relatif lebih mahal dan waktu pemeriksaan yang lebih lama 
(dapat lebih dari 24 jam), ${ }^{16}$ sehingga diperlukan adanya alternatif pemeriksaan lain yang memiliki tingkat akurasi setara namun dengan biaya yang lebih murah dan waktu pemeriksaan yang lebih cepat. Pemeriksaan eosinopenia dan rasio neutrofil/limfosit merupakan metode alternatif lain yang dapat dipertimbangkan untuk membantu menegakkan diagnosis sepsis.

Eosinopenia pada kondisi infeksi akut diperkirakan dapat terjadi akibat proses sekuestrasi eosinofil di lokasi infeksi, serta akibat respon stress yang diperantarai oleh kortikosteroid adrenal dan epinefrin, oleh karena itu, kondisi ini dapat dimanfaatkan untuk membedakan antara kondisi sepsis yang diakibatkan oleh infeksi dengan Systemic Inflammatory Response Syndrome (SIRS) yang diakibatkan oleh penyebab non-infeksius. ${ }^{21,22}$ Eosinopenia merupakan salah satu biomarker yang terbukti sensitif dan spesifik untuk mengidentifikasi adanya sepsis. ${ }^{23,24}$

Pemeriksaan petanda infeksi selain eosinofil yang dapat digunakan adalah jumlah leukosit dan neutrofil. Rasio neutrofil/limfosit dapat digunakan sebagai penanda inflamasi dan stres yang sederhana, cepat, dan hemat pada pasien dengan kondisi penyakit kritis. ${ }^{25}$ Peningkatan rasio neutrofil/limfosit memiliki sensitivitas dan spesifisitas yang tinggi sebagai penanda diagnostik sepsis. ${ }^{27}$ Respon imunitas terhadap infeksi umumnya ditandai oleh peningkatan jumlah neutrofil dan penurunan jumlah limfosit. ${ }^{5,26}$ Neutrofilia pada kondisi infeksi akut umumnya terjadi akibat penurunan apoptosis dan meningkatnya mobilisasi neutrofil dari sumsum tulang yang diperantarai oleh kemokin. ${ }^{5}$ Limfopenia, sebaliknya diakibatkan oleh berkurangnya mobilisasi limfosit teraktivasi ke jaringan yang mengalami inflamasi disertai dengan meningkatnya apoptosis limfosit. ${ }^{5,22}$

Penggunaan kondisi eosinopenia dan rasio neutrofil/limfosit untuk memprediksi diagnosis sepsis ini memiliki keuntungan dari segi biaya dan kecepatan pemeriksaan, karena pemeriksaan hitung eosinofil, neutrofil dan limfosit umumnya sudah dilakukan secara rutin pada praktek klinis sehari-hari sehingga tidak akan ada biaya tambahan yang perlu dibayar dan hasil pemeriksaan dapat diperoleh dalam waktu yang relatif cepat. $^{21}$ Perbandingan efektivitas dari kedua biomarker ini dengan procalcitonin umumnya masih belum diketahui dengan jelas. Perlu dilakukan penelitian lebih lanjut untuk mengetahui keandalan dari kedua jenis biomarker ini sebagai alternatif yang lebih hemat dan cepat dari pemeriksaan kadar procalcitonin pada pasien sepsis.

\section{METODE}

Penelitian analitik observasional ini telah dilakukan dengan pendekatan belah lintang (cross sectional) yang melibatkan 43 pasien sepsis yang dirawat di RSUP Dr. Kariadi mulai dari bulan Desember 2018 smapai Juni 2019, ada 22 pasien berjenis kelamin wanita dan 21 berjenis kelamin pria, dengan kisaran usia 25 sampai 84 tahun. Data kadar procalcitonin, jumah eosinofil, neutrophil dan limfosit diambil secara retrospektif dari catatan medis pasien setelah diperoleh ijin penelitian dengan Ethical Clearance dari Komisi Etik Penelitian Kedokteran dan Kesehatan RSUP dr. Kariadi-Semarang. Pasien dianggap mengalami sepsis bila menunjukkan nilai skor SOFA $\geq 2$ (menurut kriteria Sepsis 3 ). ${ }^{1}$

\section{HASIL}

Data rekam medis menunjukkan bahwa pasien sepsis pada penelitian ini memiliki kadar procalcitonin antara 2,19 - 87,29 ng/mL dengan median 13,8 $\mathrm{ng} / \mathrm{mL}$. Liu et al melakukan sebuah penelitian metaanalisis yang menemukan adanya hubungan antara peningkatan konsentrasi procalcitonin dengan peningkatan risiko mortalitas pada pasien sepsis. ${ }^{15}$ Peningkatan kadar procalcitonin sampai $\geq 2 \mathrm{ng} / \mathrm{mL}$ nampak berhubungan dengan diagnosis sepsis. Penelitian lain di Amerika Serikat melaporkan bahwa pemeriksaan kadar procalcitonin dengan nilai cutoff 1,5 ng/L memiliki sensitivitas sebesar $84 \%$, spesifisitas sebesar $92 \%$, nilai prediksi positif sebesar $90 \%$, dan nilai prediksi negatif sebesar $87 \%$ untuk mendiagnosis adanya sepsis. ${ }^{16}$ 
Tabel 1. Data deskriptif subjek penelitian.

\begin{tabular}{|c|c|c|c|c|c|}
\hline & $\mathbf{f}$ & $\%$ & $\begin{array}{c}\text { Rerata } \\
\pm S D\end{array}$ & $\begin{array}{c}\text { Median } \\
\text { (min - } \\
\text { maks) }\end{array}$ & $\mathbf{p}^{\varepsilon}$ \\
\hline Laki-laki & 21 & 48,8 & & & \\
\hline Perempuan & 22 & 51,2 & & & \\
\hline Umur & & & $\begin{array}{c}59,84 \\
\pm \\
13,70\end{array}$ & $\begin{array}{c}59(25- \\
84)\end{array}$ & 0,084 \\
\hline Leukosit & & & $\begin{array}{r}18,86 \\
\pm 7,18\end{array}$ & $\begin{array}{c}17,95(4,5 \\
-32,29)\end{array}$ & 0,096 \\
\hline $\mathrm{Hb}$ & & & $\begin{array}{l}10,30 \\
\pm 2,31\end{array}$ & $\begin{array}{c}10,6(5,2 \\
-14,6)\end{array}$ & $0,419^{\prime}$ \\
\hline Trombosit & & & $\begin{array}{c}243,00 \\
\pm \\
119,72\end{array}$ & $\begin{array}{c}196(40- \\
535)\end{array}$ & 0,015 \\
\hline Procalciton & & & $\begin{array}{c}29,44 \\
\pm \\
27,41\end{array}$ & $\begin{array}{c}13,8(2,19 \\
-87,29)\end{array}$ & 0,000 \\
\hline $\mathrm{N} / \mathrm{L}$ rasio & & & $\begin{array}{c}24,13 \\
\pm \\
15,26\end{array}$ & $\begin{array}{c}19,39 \\
(7,59- \\
68,36)\end{array}$ & 0,000 \\
\hline Eosinofil & & & $\begin{array}{c}0,02 \pm \\
0,02\end{array}$ & $\begin{array}{c}0,01(0- \\
0,1)\end{array}$ & 0,000 \\
\hline
\end{tabular}

Kadar eosinofil dari pasien sepsis pada penelitian ini berkisar antara $0-0,1 \times 10^{3} / \mu \mathrm{L}$ dengan median $0,01 \times 10^{3} / \mu \mathrm{L}$. Pasien dianggap mengalami eosinopenia bila menunjukkan kadar eosinofil absolut sebesar $\leq 0,05 \times 10^{3} / \mu \mathrm{L}$. Penelitian terdahulu menemukan bahwa kondisi eosinopenia merupakan suatu biomarker yang terbukti sensitif dan spesifik untuk mengidentifikasi adanya sepsis pada pasien yang dirawat di ICU maupun instalasi gawat darurat. ${ }^{23,24}$ Sementara itu, rasio neutrofil/limfosit pada subjek penelitian ini berkisar antara 7,59 - 68,36 dengan median 19,39. Subjek penelitian dianggap mengalami peningkatan rasio neutrofil/limfosit bila diperoleh nilai rasio sebesar $\geq 5$. Penelitian di Italia menemukan adanya perbedaan rasio neutrofil/limfosit yang bermakna antara pasien dengan sepsis dan tanpa sepsis. ${ }^{5}$ Penelitian prospektif lainnya di India menemukan bahwa rasio neutrofil/limfosit dengan nilai cutoff 7 memiliki sensitivitas sebesar 86,2\%, spesifisitas sebesar 85,7\%, nilai prediksi positif sebesar $89,2 \%$, dan nilai prediksi negatif sebesar $81,1 \%$ dalam memprediksi diagnosis dan prognosis sepsis. ${ }^{28}$ Eosinopenia pada infeksi akut diperkirakan terjadi akibat proses sekuestrasi eosinofil di lokasi infeksi serta sebagai bagian dari respon normal terhadap kondisi stress akibat infeksi yang diperantarai oleh kortikosteroid adrenal dan epinefrin. ${ }^{23,24}$

Uji korelasi spearman tidak menemukan adanya hubungan yang bermakna antara kadar procalcitonin dengan kondisi eosinopenia $(p=0,929 ; r=0,014)$ dan rasio neutrofil/limfosit ( $p=0,879 ; r=-0,024)$ pada pasien sepsis yang dirawat di RSUP Dr. Kariadi selama periode penelitian. Hasil ini nampak berbeda dengan penelitian terdahulu dari Shaaban et al di Amerika Serikat yang menemukan adanya hubungan yang bermakna antara eosinopenia dan kadar procalcitonin pada pasien sepsis yang dirawat di ICU, ${ }^{16}$ Penelitian dari Ljungstrom et al di Swedia yang menemukan bahwa procalcitonin dan rasio neutrofil/limfosit memiliki akurasi yang setara untuk menegakkan diagnosis sepsis meskipun tidak dilakukan analisis untuk mengevaluasi adanya hubungan langsung antara kedua biomarker ini. ${ }^{9}$

Tabel 2. Hubungan antara rasio $\mathrm{N} / \mathrm{L}$ dengan kadar procalcitonin.

\begin{tabular}{lccc}
\hline \multirow{2}{*}{ Variabel } & \multicolumn{2}{c}{$\mathbf{N} / \mathbf{L}$ rasio } & \multirow{2}{*}{ Keterangan } \\
\cline { 2 - 3 } & $\mathbf{p}{ }^{\text {\# }}$ & $\mathbf{r}$ & \\
\hline Procalciton & 0,879 & $-0,024$ & Tidak signifikan \\
\hline Keterangan : "Korelasi spearman's &
\end{tabular}

Tabel 3. Hubungan antara kadar eosinofil dengan kadar procalcitonin

\begin{tabular}{cccc}
\hline \multirow{2}{*}{ Variabel } & \multicolumn{2}{c}{ Eosinofil } & \multirow{2}{*}{ Keterangan } \\
\cline { 2 - 3 } & $\mathbf{p}^{\text {" }}$ & $\mathbf{r}$ & \\
\hline Procalciton & 0,929 & 0,014 & Tidak signifikan \\
\hline Keterangan : "Korelasi spearman's &
\end{tabular}

\section{PEMBAHASAN}

Perbedaan antara hasil yang diperoleh pada penelitian ini dengan sejumlah penelitian terdahulu dapat disebabkan oleh beberapa faktor, antara lain seperti pengambilan data yang dilakukan secara retrospektif dari catatan medis, kecilnya jumlah sampel yang digunakan akibat kurangnya jumlah pasien sepsis yang memenuhi kriteria inklusi selama masa penelitian, serta kurang seragamnya waktu pengambilan sampel untuk pemeriksaan. Seperti dijelaskan oleh Stamatis et al terdapat pitfalls dalam penggunaan eosinopenia dan Rasio Neutrofil limfosit 
sebagai biomarker penanda infeksi yaitu pemberian obat-obatan seperti kortikosteroid yang dapat mempengaruhi jumlah eosinofil, neutrofil dan limfosit. Idealnya sampel yang digunakan adalah pasien yang belum teridentifikasi mengalami infeksi. ${ }^{29}$ Penggunaan sampel yang sudah jelas mengalami infeksi dalam penelitian ini dapat menyebabkan overestimasi terhadap hasil pemeriksaan.

\section{SIMPULAN}

Hubungan yang bermakna antara kadar procalcitonin dengan kondisi eosinopenia dan peningkatan rasio neutrofil/limfosit pada pasien sepsis tidak ditemukan. Hasil penelitian ini belum dapat mendukung penggunaan pemeriksaan kadar eosinofil dan rasio neutrofil/limfosit sebagai pengganti pemeriksaan procalcitonin untuk membantu menegakkan diagnosis sepsis.

\section{UCAPAN TERIMA KASIH}

Terima kasih kepada semua pihak yang telah membantu terlaksananya penelitian ini. Kepada staf rekam medik RSUP dr.Kariadi Semarang yang sangat membantu penulis dalam mengumpulkan data penelitian, kepada pembimbing yang memberikan masukanmasukan yang berharga, serta semua pihak yang tidak dapat kami penulis sebutkan satu persatu.

\section{DAFTAR PUSTAKA}

1. Singer $M$, Deutschman CS, Seymour CW, Shankar-Hari M, Annane D, Bauer M, et al. The third international consensus definitions for sepsis and septic shock (sepsis-3). JAMA. 2016; 315(8):801-10.

2. Gaieski DF, Edwards JM, Kallan MJ, Carr BG. Benchmarking the incidence and mortality of severe sepsis in the United States. Crit Care Med. 2013;41(5):1167-74.

3. Iwashyna TJ, Cooke CR, Wunsch H, Kahn JM. Population burden of long-term survivorship after severe sepsis in older Americans. J Am Geriatr Soc. 2012;60(6):1070-7.
4. Vincent JL, Marshall JC, Namendys-Silva SA, et al. ICON Investigators. Assessment of the worldwide burden of critical illness: the Intensive Care Over Nations (ICON) audit. Lancet Respir Med. 2014; 2(5):380-6

5. Westerdijk K, Simons KS, Zegers M, Wever PC, Pickkers $P$, de Jager CPC. The value of the neutrophil-lymphocyte count ratio in the diagnosis of sepsis in patients admitted to the Intensive Care Unit: A retrospective cohort study. PLoS One. 2019;14(2):e0212861.

6. Vincent JL, Rello J, Marshall J, Silva E, Anzueto A, Martin CD, et al. International study of the prevalence and outcomes of infection in intensive care units. JAMA. 2009; 302(21):2323-9.

7. Kaushik R, Gupta M, Sharma M, Jash D, Jain N, Sinha N, Chaudhry A, Chaudhry D. Diagnostic and prognostic role of neutrophil-to-lymphocyte ratio in early and late phase of sepsis. Indian J Crit Care Med. 2018;22(9):660-3.

8. Iwashyna TJ, Ely EW, Smith DM, Langa KM. Longterm cognitive impairment and functional disability among survivors of severe sepsis. JAMA. 2010; 304(16):1787-94.

9. Ljungström L, Pernestig AK, Jacobsson G, Andersson R, Usener B, Tilevik D. Diagnostic accuracy of procalcitonin, neutrophil-lymphocyte count ratio, C-reactive protein, and lactate in patients with suspected bacterial sepsis. PLoS One. 2017;12(7):e0181704.

10. Jacobs L, Wong HR. Emerging infection and sepsis biomarkers: will they change current therapies? Expert Rev Anti Infect Ther. 2016; 14 (10):929-41.

11. Sandquist M, Wong HR. Biomarkers of sepsis and their potential value in diagnosis, prognosis and treatment. Expert Rev Clin Immunol. 2014; 10(10): 1349-56.

12. Marik PE. Don't miss the diagnosis of sepsis! Crit Care. 2014 Sep 27;18(5):529.

13. Jin M, Khan Al. Procalcitonin: Uses in the clinical laboratory for the diagnosis of sepsis. Laboratory Medicine. 2010; 41(3):173-7.

14. Kibe S, Adams K, Barlow G. Diagnostic and prognostic biomarkers of sepsis in critical care. $J$ Antimicrob Chemother. 2011;66(Suppl 2):ii33-40. 
15. Liu D, Su L, Han G, Yan P, Xie L. Prognostic value of procalcitonin in adult patients with sepsis: a systematic review and meta-analysis. PLoS One. 2015;10(6):e0129450.

16. Shaaban H, Daniel S, Sison R, Slim J, Perez G. Eosinopenia: Is it a good marker of sepsis in comparison to procalcitonin and C-reactive protein levels for patients admitted to a critical care unit in an urban hospital? J Crit Care. 2010;25(4):570-5.

17. Luzzani A, Polati E, Dorizzi R, Rungatscher A, Pavan R, Merlini A. Comparison of procalcitonin and C-reactive protein as markers of sepsis. Crit Care Med 2003;31:1737-41.

18. Brunkhorst FM, Wegscheider K, Forycki ZF, Brunkhorst $\mathrm{R}$. Procalcitonin for early diagnosis and differentiation of SIRS, sepsis, severe sepsis and septic shock. Crit Care. 1999;3:95.

19. Muller B, Becker KL, Schachinger H, Rickenbacher PR, Huber PR, Zimmerli W, et al. Calcitonin precursors are reliable markers of sepsis in a medical intensive care unit. Crit Care Med 2000; 28:977-83.

20. Balcl C, Sungurtekin H, Gurses E, Sungurtekin U, Kaptanoglu B. Usefulness of procalcitonin for diagnosis of sepsis in intensive care unit. Crit Care 2003;7:85-90.

21. Garnacho-Montero J, Huici-Moreno MJ, GutiérrezPizarraya A, López I, Márquez-Vácaro JA, Macher $\mathrm{H}$, et al. Prognostic and diagnostic value of eosinopenia, C-reactive protein, procalcitonin, and circulating cell-free DNA in critically ill patients admitted with suspicion of sepsis. Crit Care. 2014; 18(3):R116
22. Karakonstantis S, Kalemaki D, Tzagkarakis E, Lydakis C. Pitfalls in studies of eosinopenia and neutrophil-to-lymphocyte count ratio. Infect Dis (Lond). 2018;50(3):163-74.

23. Abidi K, Khoudri I, Belayachi J, Madani N, Zekraoui $\mathrm{A}$, Zeggwagh $\mathrm{AA}$, et al. Eosinopenia is a reliable marker of sepsis on admission to medical intensive care units. Crit Care. 2008;12(2):R59.

24. Lavoignet CE, Le Borgne $P$, Slimani $H$, Forato $M$, Kam C, Kauffmann $\mathrm{P}$, et al. Relevance of eosinopenia as marker of sepsis in the emergency department. Rev Med Interne. 2016;37:730-4.

25. Zahorec R. Ratio of neutrophil to lymphocyte counts-rapid and simple parameter of systemic inflam- mation and stress in critically ill. Bratisl Lek Listy. 2001;102(1):5-14.

26. Khajuria R, Jamwal V, Gupta AK, Gupta A. Evaluation of eosinophil count and neutrophillymphocyte count ratio versus C-reactive protein levels in patients with sepsis. Int $\mathrm{J}$ Res Med Sci. 2017;5(11):4754-60.

27. Wilar R. Diagnostic value of eosinopenia and neutrophil to lymphocyte ratio on early onset neonatal sepsis. Korean J Pediatr. 2018; 62 (6): 217-23.

28. Hota PK, Reddy G. Role of eosinophil count and neutrophil: lymphocyte count ratio as prognostic markers in patients with sepsis. Int Surg J. 2017; 4 (7):2243-6.

29. Stamatis K, Dimitra K, Emmanouil $T$ \& Charalampos L. Pitfalls in studies of eosinopenia and neutrophil-to-lymphocyte count ratio. Infectious Diseases, 2018;50(3):163-74. 